\title{
Top Seven Polish Science Fiction Novels of the Communist Era (Lem aside)
}

\begin{abstract}
With the exception of Lem's works, Polish science fiction of the communist era is largely forgotten. AngloAmerican readers know only fragments of Lem's literary work, and they know almost nothing about other Polish science fiction writers. The aim of this article is to familiarize Anglo-American audience with seven Polish science fiction novels written in the communist era: Farther than Hatred (Dalej niż nienawiść) by Wojciech Bieńko (1963); Aspasia (Aspazja) by Andrzej Ostoja-Owsiany (1958); To Drain the Sea (Wyczerpać morze) by Jan Dobraczyński (1961); Arsenal (Arsenat) by Marek Oramus (1985); Paradisia (Paradyzja) by Janusz A. Zajdel (1984); The Robot (Robot) by Adam Wiśniewski-Snerg (1977); Imago (Imago) by Wiktor Żwikiewicz (1985).
\end{abstract}

Key words: science fiction, novel, Polish, communist era.

Is there still a need for writing about Stanisław Lem's influence on Polish science fiction after World War II? Is that not peculiar and actually boring that every "the very best" list anybody could imagine is filled tightly and almost completely with Lem's works? And it does not matter whether we choose novels or short stories. Anglo-American readers know only fragments of his literary work, and they know almost nothing about other Polish science fiction writers.

Consequently, I think it is worth trying to delve into the shadow cast by Stanisław Lem, primarily because we (readers, critics, scholars, and writers) are no longer living under it. The nearest future will bring a wave of re-evaluation of the famous writer's oeuvre. It is already happening in reference to futurological and philosophical works. But, let us be fair, it happened, at least in Poland, from the beginning of Lem's aspiring efforts in that field, just after he had made them public. It is true that Lem did not compete with anybody, he was just trying-in his own awkward way-to establish a real dialogue with minds like Leszek Kołakowski's. Without a satisfying effect (Csicsery-Ronay 1964: 452). Far from it. Lem was genuinely disappointed.

And then, the crowd (mainly "fandom") famously crowned another king-Adam WiśniewskiSnerg-by selecting his novel, The Robot (1973), as the best fantastic novel of the three post-war de- 
cades in Poland. It was something new and quite fresh. The Robot was of course followed by several Lem's novels-"loosers". Perhaps, inevitably, it was quite "Lem-ish", on the wild side of the master.

And today? Today Stanisław Lem seems to be just another entry in contemporary literary history. He is defined by Solaris, Cyberiad and Star Diaries. Other works by Lem matter for academics and for young adult readers, who just put them on the "to read" list, on the far end of it. Actually, the throne was not taken by anyone. There were aspiring writers, of course: Adam WiśniewskiSnerg in the "70s, Janusz A. Zajdel in the ' 80 s. Yet the throne of the most influential, or even "the best", Polish SF writer remained empty, hidden in a cold dry place and covered in dust. But a radically new constellation of writers emerged in the 1990s. And it looks like one of them-Jacek Dukaj (Kozicka 2013: 109-112), the quite "Lem-ish" one-has been building his own "throne". Unlike Lem, though, he does like the science fiction? genre, mainly for its experimental nature and for the immersive world-building (Maj 2015: 391-391). Or, it is not a matter of such things as "thrones" or "podiums" anymore. Now, it is important to be in the center of the stream, to be non-stop present. The future-present orientation, characteristic of societies built on competition, prefers the promise of continuity to dwelling in the abstract past. Michael Kandel, a prolific translator of Lem's works, is now promoting a contemporary Polish writer Marek S. Huberath. It is important-and ironically enough-because still requires remembering Lem. Huberath's novel Nest of Worlds (Gniazdo światów) was published recently and the publication was recorded in the milieu (Huberath 2014). It received well deserved critical and readerly notice.

Let us come back to the earlier, shadowy landscape. The Soviet regime, communist cultural and social pressure, cold war, the Iron Curtain and the birth of the Solidarity movement defined forty years of Polish literature, 1949 to 1989. My generation-people born in the '70s-used to think it was a very long period of time, mainly because we spent our childhood within its last phase, but that is not quite right. Let us consider: 1989 happened almost 30 years ago. Many have yet to make full sense of that time, in a way that would allow them to move on with new energy. Many of us are still stuck in "eighties-haties", as Morrissey once called the decade'. Many of us completed literary and musical self-education in those colourful years, but got ready to be overwhelmed by something really, really big. The future was unclear, and the year 2000 almost a fairy-tale. We were just "a waiting generation". But we read a lot, and had stable preferences already "worked out".

My aim in this paper is to share my own view, perhaps nostalgic, and controversial in few cases, on those forty years when science fiction was not welcome in the Polish academia (Lem aside) and super-official literary institutions. My primary motivation is to unleash, discover the meaning of Polish science fiction with Lem "suspended". I gathered, in memory and on my table, all Polish SF novels I have read and remembered, and then took seven of them, which counted then and count now, albeit differently. These were the two conditions: the past future had to be worth reading in its own nostalgic way, or just "re-futured", read as science fiction as it would be written today.

1 http://urbandictionary.com - haties [17.10.2017]. 
So, here come seven Polish communist era novels that should be, in my opinion, remembered, Some of them are being forgotten in the very moment of writing this sentence. Just remember, most of them could be kicked out or down by Lem's novels, but not without discussion. And the discussion is everything I hope for.

\section{Wojciech Bieńko: Farther than Hatred}

\section{(Dalej niż nienawiść), 1963}

Science fiction has been built by insiders, genre writers and genre fans. It evolved with them, got significantly better when they learned more and more about the genre's potential, its flaws and merits, until finally they reached a point of creative distance from the genre's center. But there were also outsiders, writers who had the comfort of looking from the mainstream, ignorance or the avant-garde. One of them, not specifically established as a writer, was Wojciech Bieńko. His not-so-famous novel reintroduces a discursive mode of fiction, so you can often "hear" the grinding between narration and the idea. The story of a mathematician discovering possible worlds and, through the process of discovery, turning them into real alternatives, is nevertheless still important.

The narration is awkward in itself, not very well balanced between the first-person and thirdperson poles, but the flaws are not meaningless here. On the contrary. They make the complete sense. Lem's futurological and xenological treatises are the nearest references. Bieńko and Lem were quite close to didactic narratives, but both of them resisted banal transparency. It is fiction in itself and science fiction for its own reasons. Bieńko's effort is not even close to Lem's in terms of literary value, but it is still comprehensive in terms of cosmic and existential semiotics (when signs reveal worlds). As science fiction it still matters. The plotting is quite fine sometimes, and sometimes it seems like pulp-driven boredom. Nothing is lost. Remember, as Samuel R. Delany wrote, science fiction is a "paraliterature" and should therefore be judged by its own criteria, as idiosyncratic fiction not fond of invasive mimetic reduction.

\section{Andrzej Ostoja-Owsiany: Aspasia (Aspazja), 1958}

This novel, though sometimes very rough in terms of style and rhetoric, offers an interesting view of colonialist wars. Mars has to be explored just because it is resistant to exploration. A pack of Earthmen of a subsequent rescue and exploration expedition meets a Martian intellect that is seductive, alien, and so natively safe at the same time. But the human urge for knowledge is destructive. Humanity is a Borg-like entity assimilating every otherness it meets. Martian bee-like aliens, organised in a swarm manner, are buried under a tone of proliferating theories, mirroring effects, ethical hesitancy, and indecisiveness. Ostoja-Owsiany took an exercise in depicting two models of the collective mind: extrovert humankind and introvert Martian pseudo-society. Both are stable in an illusionary way. Their main goal is to keep the illusion going.

Ostoja-Owsiany's novel cannot be counted among the best science fiction novels because of its mediocre character and plot building, but it remains interesting and quite ahead of its times as far as thematic concerns are taken into account. It predates a gender buzz combining it with the 
now trending idea of the collective mind. If the reader is able to separate idea and narrative, it is a must-read.

\section{Jan Dobraczyński: To Drain the Sea}

(Wyczerpać morze), 1961

Dobraczyński's novel, depicting the restoring of the Catholic Church after nuclear disaster, was translated into English, among few other languages. As an almost typical representative of the post-apocalyptical subgenre, it takes its chance to clarify the situation, and to introduce utopiandystopian intellectual and moral dynamics. It is an obvious counterpoint to Walter M. Miller's $A$ Canticle for Leibowitz. If humankind (western civilization) is to survive and grow, it has to learn a lesson and rebuild its self-esteem and moral stability. The crisis stimulates personal activity and requires order and hierarchy of beliefs. The knowledge of the past must be gathered to test the reordering power of the extreme.

To Drain the Sea is a fine read and thorough testing exploration of values characteristic of Catholic societies. It could start quite a discussion, since it is controversial in a few cases, but-after all-what is not?

\section{Marek Oramus: Arsenal (Arsenat), 1985}

Oramus is a representative of the generation born just after the war. They came to their voice right before the Martial Law and strengthened their presence thanks to the dystopian subgenre accompanying the political transformations of the eighties. This sub-genre also articulated, on some level, the changes that were occurring. What is worth mentioning in the case of Oramus's novel is its vivid style, very natural, essentially satirical. The plot is not easy to recount. The novel is not a very easy read, because of the visual allegory and onirism mix projected onto traditional "first contact" plot, a tale of the totalitarian (and a bit messy) approach to the contact. Polish critics of the generation were fascinated by the turn from outer space to "innerspace", psychology and personal world-vision.

The novel is original, but also dominated by an attitude close to Lem's, who became a touchstone of dark humor and pessimism, perhaps even of misanthropy.

\section{Janusz A. Zajdel: Paradisia (Paradyzja), 1984}

Zajdel's novel belongs to the famous - at least in Poland-literary movement called "fantastyka socjologiczna", a subgenre of dystopia born in the late seventies. Very lively between 1979 and 1989, this sub-genre officially focused on universal frames of social behaviour in totalitarian states (Leś 2008). Most literary critics see the movement as a counterpoint to the rise of Solidarity ideas, contestation of communism, and finally-the fall of socialist economics. Being an allegory and a systematic analysis of repressive paradigms of power at the same time, "fantastyka socjologiczna" (Polish science fiction focused on social, totalitarian system issues) is full of indirect political allusions. 
The most fascinating thing in the novel, when you read it today, could be the world: grey and colourful at the same time, plain and complicated, official and hidden. Zajdel was very precise in Paradisia. The relation of Earth to Paradisia, the great lie, propaganda, and fiction form almost a "fractal" narrative, where each element reflects others and entails them. Nothing is left out.

Paradisia is a complex analysis of transparency and opaqueness in politics, everyday life, and artificial humans in artificial worlds. Nikor, the fictional science fiction writer living on Paradisia, is very close to the truth. Zajdel's novel touches the very essence of fiction (including science fiction) writing. A complex, self-conscious vision, rich in allegory, irony, and metaphor. On the other end, the matter inevitably deteriorates. Things change because they exist. The rust gives hope.

\section{Adam Wiśniewski-Snerg: The Robot (Robot), 1977}

The story about the illusionary contact with an alien intellect and a robot seeking his identity is beautifully unbalanced and fiercely overdone. It has the kind of cognitive shock science fiction is meant to have.

This is the novel that was leading the pack of Lem's novels in the famous voting mentioned earlier in this paper. It was fresh then, clever and wild at the same time, characteristics that became a significant part of Lem's oeuvre, as visible in Futurological Congress. But there was also a difference or differences. Immersion. Identifying with a fictional character and the world he lives in, emotional reembodiment, whatever you call this phenomenon. While reading Lem's novels I was committed to the admiration of the author's intellect. And, when I project my feelings onto the chronological order of Lem's writings, things are getting worse and worse. The admiration became cold-hearted. The Robot required the same intellectual attitude, which every skeptic or every astute reader adopts on the high-brow level, mainly the belief that there is something out there we do not know about, and very limited faith (or strong doubt) in the effectiveness and authenticity of communication. In this particular case, this attitude was emotionally undermined. You can feel the struggle.

\section{Wiktor Żwikiewicz: Imago (Imago), 1985}

This was a writerly story fans did not really like. It is the thickest of all the books mentioned here, originally published in two (paperback) volumes. Żwikiewicz brilliantly refreshes and obscures the plotting pattern of exploration and confrontations with an alien point of view and being, but he does it in his own severely weird way. No summary can convey this weirdness, the complexity and overdose of metaphorical and tricky rhetoric. The reader takes it all, but never wins. The dense style connects living language, cognition, visions and known-unknown biology. The novel is a wonderful mix of crossword-like mysteries confronted with the reader's rejection of enigmatic world-building. It is an exercise in cross-genre imagination, an almost mystic or, at least, psychedelic one. It may be close to Lem's Solaris, but far weirder, extended, bravely deconstructed. A satisfying and memorable effort, and yes - hard to read. But, the reader's active patience mirrored by the protagonist's boredom should finally pay off. 
Lem aside, Polish science fiction of the communist era is largely forgotten. Although not really competitive with the Anglo-American model of the genre, it does have its brighter (or actually darker, dystopian) side. As mentioned above, the choice of seven novels was a result of my own sentiments, but, sadly perhaps, there is not much more material to build another, totally different, list.

\section{References}

Csicsery-Ronay, Istvan. 2013. The Summa and the Fiction. Science Fiction Studies 3. 451-462.

Huberath, Marek M. 2014. Nest of Worlds. Michael Kandel (translation). Brooklyn: Restless Books. Kozicka, Dorota. 2013. Fantastyczni pisarze, czyli o tym, jak pisarze fantastyczni podbijają polską literaturę. Wielogłos, 4. 105-116.

Leś, Mariusz. 2008. Fantastyka socjologiczna. Poetyka i myślenie utopijne. Białystok: Wydawnictwo Uniwersytetu w Białymstoku.

Maj, Krzysztof M. 2015. Czas światoodczucia. Imersja jako nowa poetyka odbioru. Teksty drugie 3. 368-394. 